\title{
TEACHERS' NONVERBAL COMMUNICATION IN ENGLISH TEACHING AND LEARNING PROCESS
}

\author{
Rindilla Antika ${ }^{1)}$, M.Khairi Ikhsan ${ }^{2)}$ \\ STKIP PGRI Sumatera Barat \\ E-mail: ${ }^{1}$ dillarindilla@ gmail.com, ${ }^{2}$ khairi84ikhsan@gmail.com
}

Submit: 13-08-2018 Review: 18-08-2018 Accepted: 23-08-2018

DOI: https://doi.org/10.22202/tus.2018.v4i1.2799

\begin{abstract}
Nonverbal communication is one of the communication types which are done in teaching and learning process. This research aims to analyze nonverbal communication types done by teachers in English teaching and learning process in SMP Negeri 10 Padang. It is a descriptive research in which the participants are two English teachers which taught at VII Grade SMP Negeri 10 Padang. The data were collected through observation checklist and field note and were analyzed by using Schmitz's (2012) nonverbal communication theory. The result of the research shown that teacher at VII Grade SMP Negeri 10 Padang used nonverbal communication types such as Kinesics; using movement, Vocalics; using voice and intonation, and Proxemics; using distance, however, the teachers did not use Haptics, using touch, in English teaching and learning process. In conclusion, English teachers at VII Grade SMP Negeri 10 Padang had used nonverbal communication types and applied them in teaching and learning process.
\end{abstract}

Keywords: Communication, English, Nonverbal, Teaching and Learning Process

\section{INTRODUCTION}

Communication is the art and process of creating and sharing ideas. Art and process in communication mean what the people have in their mind; how they filter it and how to communicate exactly, then what they want to say. Communication cannot be separated with human life (Panjaitan, et.all, 2017:33). General communication consist of verbal and non verbal that can be understood by the speaker and listener, verbal communication is communication using word either spoken or written to understand the meaning. If the speaker and listener cannot understand and communicate the meaning in verbal language, communication can still be done by 
using nonverbal communication. Nonverbal communication is a process of communication in which the message is delivered not using the word. It is also through signs and symbols when speaker and listener doing communication. It is the unspoken communication that goes on in every face to face encounter with another human being (Xu, et.al, 2009: 20664).

Communication also happens in teaching and learning process. In teaching learning process, communication happened between teacher and students, for example teachers explain the material to the students and the students ask the question to the teacher. In this situation, the teachers explain the material verbally and use gestures and expression. It is intended to make the students understand what the teacher has said. In other word, by using gestures and expression in explaining the materials, it can help the students easier to understand the materials. Gestures and expressions belong to nonverbal communication (Xu, et.al, 2009: 20664). In communication, especially in teaching and learning process, the teacher uses verbal and nonverbal communication.

Non verbal communication can make listeners trust what the speakers talking about and can give opportunity for the speakers to look up audiences that interesting or not with the material. As teacher they should build good communication among the students, teacher should speak clearly to their students. If teacher cannot use nonverbal communication well in learning process, it will cause communication in teaching learning process and the aim of teaching learning cannot be achieved. In addition, the teacher must deliver positive atmosphere, and also can improve their communication skill and train them to talk to a group of people. In the class the teacher can give information about the topic and the content with simply word or use their own word. Sometimes the students did not read and familiar about topic, so the teachers help them to understand topic easily. The teachers actually use verbal communication that is the point of teacher says using word in explaining material, but it will not complete when teacher did not use nonverbal, and can make relationship between teacher and students. For example, the teacher walked from the desk toward, 
the students opened a book, look down at a question in the book. Therefore it can help teacher in explaining material. It also can make students easier understand the material and it will make the class is more interesting.

In fact, based on the researcher pre-observation, the researcher found phenomenon during teacher's non verbal communication in teaching learning proccess. When the teacher explained about material, the teacher sometimes move her hand to emphasize her explanation or she raised her intonation to call students' name. It is called as "non verbal communication", which is used to make relationship between teacher and students. However, the teacher sometimes did not use nonverbal communication when explaining the material. Sometimes, the students only focus on the slide or the paper when the teacher told the material. It made the teaching learning be boring and not interesting. Based on the phenomenon above, the researcher interests to describe what are the teachers' non verbal communicationin English teaching learning process at SMPN 10 Padang.

Teaching and learning process is a system that should be followed by the students to reach the higher level of education. In simple, teaching and learning process can be defined as a process transferring knowledge to students. In addition, Aggarwal (2001:55) describes that teaching and learning process is a means through which the teacher, the learner, the curriculum and other variables are organized in a system manner, to attain pre determined goals and adjective. It means that there are many factors that should be considered in teaching and learning process, such as teacher, learners and curriculum. Indeed, teaching and learning process should pay attention not only about the physical of the class but also interaction that occurs in the class. Thus, the classroom atmosphere is good. Furthermore, Sankaranarayanan and Sindhu (2012:95) argues that teaching learning process is aimed acquisition of knowledge, skill and attitude which enable the students to lead a well adjusted life. It can be explained that teaching and learning process not only focus on to build students' competence but also students' attitude. Indeed, teaching and learning 
process will be fun if the teacher is smart to handle the class. The teacher can use verbal and nonverbal communication in teaching and learning process.

Non verbal communication is an important thing in human communication. When the teachers explain the material in the teaching learning process must pay attention to the students. Teacher use non verbal communication to make them connect with students in teaching learning. Non verbal communication to help the teacher to express the word and make students easier to understand the meaning of word. Then, non verbal communication also make the students trust with the teacher explanation. Non verbal communication can give positive and negative impact. For positive impact, When teachers use non verbal communication, the students can look and attend to confidence in explaining material. According to Joseph (2002:134), non verbal communication is communication with out words, communicate non verbally when gesture, smile or of volume,eyes,move chair closer to someone, wear jewelry, touch someone, or raise vocal volum and when receives these signal. It means that, non verbal communication is communication use gesture, eyes, touch and when receives signal.

Meanwhile, Schmitz (2012:181) states that nonverbal communication is a process of generating meaning using behavior other than words. In short interacting using nonverbal means that teacher more using her/his behavior to generate the meaning from what he/she does in front of students actually it is done for giving applause to the students, the applause relates to students feedback toward teacher asking. Schmitz (2012:196) also states there are types of nonverbal communication as follow:

a. Kinesics, First, gestures, there are three main types of gesture: the first type is adaptors (it is used to reduce the arousal or anxiety. For example: shake our click pens and any others). Secondly is emblems (are gestures that have a specific agreed on meaning. For example: raised the thumbs means “ok"). The last type is illustrators (it is the most common type of gesture and used to illustrate the nonverbal massage they accompany, for example: using hand 
gesture to indicate the size or shape of an object. Head movements and posture is the head shake back and forth to signal "no" it is also used to indicate interest. Besides there is posture, there are four general human postures: sitting, standing, squatting and lying down. And the next, Eye contact, the face and eyes are the main point of focus during communicator and along with ears, eyes, take in most of the communication. Last, Facial expression, can communication fact teacher, is tired, excited, angry, confused, frustrated, sad, confident, shy or bored.

b. Haptics, refers to the study of communication by touch, touch is also an efficient way of breaking down communication berries. As the most extreme reduction or individual distance, touch is one of our most primitive and yet sensitive ways of relating to others and plays a significant role in giving encouragement, expressing tendems and showing emotional support.

c. Vocalics, is study of paralanguage, which includes the vocal qualities that go along with verbal massage, such as pitch, volume, rate, vocal, quality, and verbal filter. Paralanguage is the way people vocalize or say words. The full and connect use of paralanguage in class is a powerful tool for effective teaching and learning process.

d. Proxemics, how space and distance influence of communication. We only need to look at the ways in which space show up in common metaphors to see that space, communication, and relationship are closely related. For example, people lose connection with someone, people will react by showing their distance.

Moreover, According Hans and Hans (2015:47), there are three types of nonverbal communication in teaching learning as follow: first; body language, refers to designation for instinctive, conscious and conventional expressive movements of the body, including posture, head movements. Second; facial expressions and gesture so on. Next, Paralanguage Includes voice quality, emotion, and speaking style, as well as prosodic features such as rhythm, intonation, and stress, in line with this sentences paralanguage is related to someone spoken. Object communication includes 
clothing, hairstyle, architecture, symbols and so on. It can be said that this it is related to someone performance. Then, Devito (2002) states that there are types of nonverbal communication as follow; The Body Movement; the study of nonverbal communication through face and body movements and identify five major types and example of movements: Emblems are body gestures that directly translate into words or phrases. For example: OK, the thumbs-up for "good job”. Illustrators, the verbal massage they accompany. Example: turn your head or your entire body toward the left. Affect display, Are movement of the face. Such as: smiling and frowning. Regulators, are behaviors that monitor, control, coordinate the speaking of another individual. Adaptors, there are gestures that satisfy some personal need. such as: rubbing nose.

Other types of nonverbal communication stated by Joseph is facial communication, Facial movements alone seem to communicate the degree of pleasantness, agreement, and sympathy felt and also facial management techniques (Malandro, Barker, 1989 in Joseph 2002). Intensifying helps you to exaggerate a feeling. For example: when someone surprises someone. De-intensifying helps to underplay a feeling such as to cover up own. Neutralizing, it helps to hide feelings such as: cover up sadness. Masking, it helps to replace or substitute the expression one emotion really feeling. Example: cover up disappointment about not receiving the gift had expected. Eye movement; Making eye contact with another person is considered a sign of sincerity, caring, honesty, and sometimes power or status. Based on that explanation above, it can be concluded that there are several types of nonverbal communication such as kinesics (facial expression, body movement, gestures, eye contact), hapatics ( touch), vocalics, and proxemics. The researcher takes Schmitz's (2012:196) theory in analyzing teachers' non verbal communication types in English teaching and learning process.

The purposes of this research are: to identify by the type of teacher's nonverbal communication in teaching and learning process at SMPN 10 Padang. The result of the study intended to give information and contribution to the students and 
researcher. First, for the teacher, this research will give information about the use of nonverbal communication that can be applied by the teacher in teaching learning, and it also makes the teacher motivated to do more interaction in the classroom. For the students, after they read this research they can be easy to interaction with the teachers interaction about material and understand about the material explain from the teacher. Then, the researcher gets knowledge to explain and apply this information when doing interaction and communication in the teaching learning process.

\section{METHODS}

The researcher implements descriptive research because the researcher wants to know the use of teacher non verbal communication at SMP N 10 Padang. According to Gay and Airasian (2000: 275), descriptive research determines and describes the way things are. In choosing the participant of the research, the researcher used total sampling which means the researcher took all of English teachers who teach at VII grade of SMP Negeri 10 Padang as the participants. Since only two teachers who taught in grade VII and the researcher purposed is to investigate what are the nonverbal communication used by the teachers.

Instrument refers to variety of tools in collecting the data in a research project. As Gay and Airasian (2000: 145) state that instrument is a tool or something that is used to collect the data. In this research, the researcher uses three instrumentations to find the data during research process in the field. Marshall and Rossman in Kawulich (2005) define observation as the systematic description of events, behaviors, and artifact in the social setting chosen for study. Moreover, Gay and Airasian (2000: 213) state that field note is the record of observer's perception toward what she or he has been seen, heard. Here's the indicator of observation;

\section{No Indicator Sub indicators List of item observation}

\begin{tabular}{llll}
\hline 1 & Kinesics & a. Gestures & $\begin{array}{l}\text { English teacher manages the classroom before } \\
\text { begin the lesson. }\end{array}$ \\
\hline
\end{tabular}




\begin{tabular}{|c|c|c|c|}
\hline & & Emblems & $\begin{array}{l}\text { English teacher uses nonverbal signal to express the } \\
\text { students. }\end{array}$ \\
\hline & & Illustrator & $\begin{array}{l}\text { English teacher uses a hand gestures to show object } \\
\text { material }\end{array}$ \\
\hline & & $\begin{array}{l}\text { b. Head movement } \\
\text { and posture }\end{array}$ & $\begin{array}{l}\text { English teacher uses head movement in teaching } \\
\text { and to control the students }\end{array}$ \\
\hline & & Standing & English teacher did standing. \\
\hline & & Sitting & English teacher did sitting \\
\hline & & Squatting & English teachers did squatting \\
\hline & & Lying down & English teachers did lying down \\
\hline & & Eye contact & English teacher uses eye contact to explain material \\
\hline & & c. Facial expression & $\begin{array}{l}\text { English teachers show her facial expression to } \\
\text { express the material }\end{array}$ \\
\hline & & Happiness & English teachers have expression of happiness \\
\hline & & Sadness & English teachers have expression of sadness \\
\hline & & Fear & English teachers have expression of fear \\
\hline & & Anger & English teachers have expression of anger \\
\hline & & Disgust & English teachers have expression of disgust \\
\hline 2 & Hapatics & $\begin{array}{l}\text { Touch } \\
\text { Handshake }\end{array}$ & English teachers do handshake \\
\hline & & Pat on the arm & English teachers pat on the arm \\
\hline & & Pat on the shoulder & English teachers pat on the shoulder \\
\hline 3 & Vocalics & a. Pitch & English teachers have pitch \\
\hline & & b. Volume & English teachers have volume \\
\hline & & c. Rate & English teachers have rate \\
\hline & & d. Verbal fillers & English teachers have verbal fillers \\
\hline 4 & Proxemics & Proxemics distances & English teachers do proxemics distance \\
\hline
\end{tabular}

\section{Table 1. Indicators of observation}

In analyzing data, the researcher analyzes the data which gathered from observation checklist, field note, and video recording. In this research, the researcher collects the data about the teacher's after collecting the data, the researcher manages the data. In this case, teacher's non verbal communication in teaching learning proccess managing the data involves the process of creating and organizing the data which is collected during the study. According to Gay and Airasian (2000: 239), there are four steps to analyze the data in descriptive research, they are; reading, becoming familiar with the data and identifying the main themes. In this stage, the researcher 
will read the data from instruments. It is done to make the researcher familiar enough with the data gotten from the observation checklist, field note. The researcher also sees the video recording to make sure that those data is complete and there is suitable with the observation checklist and filed note. Describing, examining the data in depth to provide detail description of setting, participants, and activities. In this stage, the researcher describes teacher's non verbal communication in teaching learning proccess. Classifying, categorizing and coding pieces of data and physically grouping them to themes. In this stage, the researcher would classify the data and then categorize type of teacher's body language; they are facial expression, eye contact, gesture, and body movement. Interpreting, interpreting and synthesizing the organized data into general understanding. In this stage, the researcher would interpret about teacher's non verbal communication in teaching learning proccess.

\section{FINDING AND DISCUSSION}

Based on the result of observation and note, it is found that there are three types of nonverbal communication used by English teacher in teaching and learning process at SMP N 10 Padang are almost all the types. They are: kinesics, vocalics, and proxemics.

\section{Kinesics}

Based on the observation, it is found that the teacher used kinesics in teaching and learning process such as adaptors, gestures, emblems, illustrators, and facial expression. From two of participants, one participant used adaptors where she always stirs the maker with her hand. Then, she also used emblem in making nonverbal signal to the students. She used her hand to get clue about material. Next, it is also found that the teacher also used illustrator when she used her hand to invite the students to show the material in projector. Next, head movement and posture in this type, the researcher found that she used head movement to handle the classroom and manage her students to interest her like she was walking around the classroom. 
In observation, it is also found that the teacher not only stands or sits in the same place but she always walks around in the classroom. In teaching learning process she always cheks her students. She always walks around to make sure her students understand or nor about the material. Then, she also used eye contact in her teaching learning process whenever she explained the material. The teacher always used it to make nonverbal communication to the students, so students felt if their teacher was looking their activity in the class. In the other side, she also used eye contact as angry sign when their students did not pay attention for her. And the last is facial expression based in the video has taken before, the researcher also found this type. In this type she used facial expression also in her teaching learning process. She was serious when she explained the teaching learning material. The other situation, she is also smile when her classroom get funny, for example when her students get wrong in answer the question or the students activity in the back. She also makes sign angry in her face when their students not pay attention and make a mess in the classroom.

\section{Vocalics}

In vocalics type, it is divided into four parts; there are pitch, volume, rate, and verbal fillers. From the first observation is pitch. Based on the observation, it is found that the teacher used pitch in teaching learning process. The teacher used pitch sound when she gave the question for the students. Example: "do you know about this picture?" next volume, based on observation taken before the researcher found that the teacher A also used volume clearly, and make students can listen the question to students, and then rate, in this section, the teacher also used rate in teaching learning process. It can be seen, if teacher explained material step by step with slowly, so the students can understand with the material that has been given before. The last verbal fillers in this section, based on observation, the researcher not found if the teacher used it, the teacher can explain material with the good way, and also she has experience for years. Thus, the researcher did not found this type. 
At the second observation researcher found that the teacher used pitch, volume and rate. By an observation, the teacher used pitch in material example: "Apa yang kita deskripsikan ?" and the teacher volume clearly and students can easily understand, and the teacher used rate to material, explain with step by step but also over fast and make students confused. While based on observation, other teacher also used pitch, volume, rate, and verbal fillers. From the first observation is pitch. The teacher used pitch in teaching learning process. The teacher used pitch sound when explain material for the students. Example: "no comment, write your book please" next volume, based on observation has taken before the researcher found that the teacher also used volume clearly, and made students can listen the clue to students, and then rate, in this section, based on the observation, the teacher also used rate in teaching learning process. It can be seen, if teacher explained material step by step with slowly, so the students can understand with the material has given before. The last verbal fillers in this section, based on the observation, the researcher didnot found if the teacher B used it, teacher B can explain material with the good way, and also she has experience for a year. Therefore, the researcher did not found this type.

Indeed teacher B who taught in VIIB class also used pitch in material example: "no comment, write your book please" next volume, based on video has taken before the researcher found that the teacher B also used volume clearly, and make students can listen the clue to students, and then rate, in this section, based on observation, the teacher B also used rate in teaching learning process. It can be seen, if teacher explained material step by step slowly, so the students can understand with the material has given before. The last verbal fillers in this section, based on observation, the researcher not found if the teacher B used it, teacher B can explain material with the good way, and also she has experience for years. Therefore, the researcher did not found this type.

\section{Proxemics}

From the first observation is proxemics distances, based on the observation the researcher found that the teacher A used proxemics distance in the classroom, the 
teacher A used this type to the students can control interaction with students, she can know when should to come the students and when explain material. The teacher A always walking around in the classroom and do the body movement when she explain material, not only sit and stand in one stage. Next to the teacher B, based on the observation the researcher found that the teacher B used proxemics distance in the classroom, the teacher B used this type to the students can control interaction with students, she can know when should to come the students and when explain material. The teacher B always walking around in the classroom and do the body movement when she explains material, not only sits and stands in one stage. Furthermore, come to the teacher $\mathrm{A}$ and $\mathrm{B}$ used proxemics distance, based on the observation the researcher found that, the teacher A and B used proxemics distance in the classroom, the teacher used this type to her students. Teacher A and B always walk around in the classroom and do the body movement when she explained the material, teacher not only sit and stand on stage.

\section{Haptics}

From the first observation until the last observation the researcher did not found if the teacher A and teacher B did not used this type. In teaching learning process the teacher A,B only come to students have get understand in teaching learning process, and not touch students, they only walking beside students and try explained material if the students did not understand.

In teaching learning process, the teacher used almost all of type's nonverbal communication. For example teacher A: when the teacher explains material in the projector the teacher used hand to show or explain for the students. Next example teacher B. she used facial expression when teaching in the class " Dengarkan Ibuk". So, in teaching and learning process almost used all of type's nonverbal communication in teaching and learning process. In can be seen in this following table; 


\begin{tabular}{|c|c|c|}
\hline No & Indicator & SubIndicator \\
\hline 1. & Kinesics & 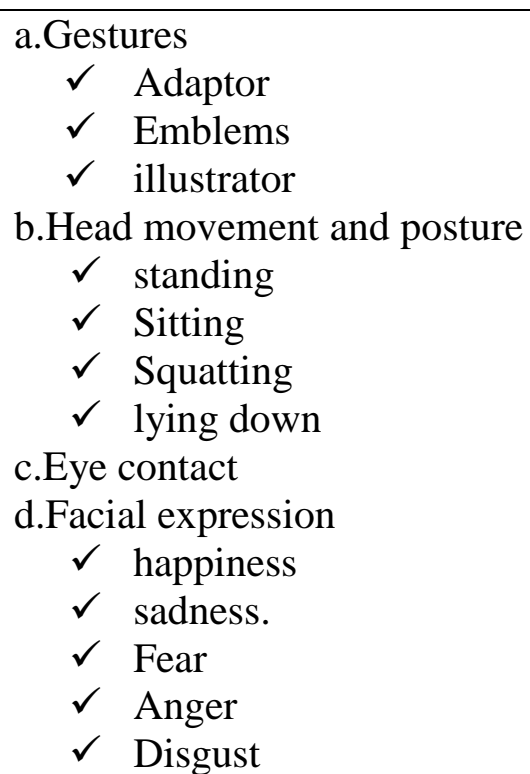 \\
\hline 2. & Hapatics & $\begin{array}{l}\text { Touch } \\
\text { Handshake } \\
\text { Pat on the arm } \\
\text { Pat on the shoulder }\end{array}$ \\
\hline 3. & Vocalic & $\begin{array}{cl}\text { Sound } & \\
\checkmark & \text { Pitch } \\
\checkmark & \text { Volume } \\
\checkmark & \text { Rate } \\
\checkmark & \text { Verbal fillers }\end{array}$ \\
\hline 4. & Proxemics & Proxemics distances \\
\hline
\end{tabular}

\section{Table 2. The Result Of Observation}

Based on data description, and finding above, the researcher had interpretation about the types of teachers' nonverbal communication. The purpose of this research was to found out how are the types of teachers' nonverbal communication in teaching and learning process at SMPN 10 Padang academic year 2017/2018. Based on observation and field note the types of teachers' nonverbal communication devide into four types that mostly appear they were kinesics,hapatics,vocalics,proxemics. However, based on observation, it is only found three types of nonverbal communication such as kinesics, vocalics and proxemics. 
Since the researcher doing this research, there are information that researcher got from this research. Most of the information can be interpreted that the English teachers at SMP 10 Padang, actually had types of teacher's nonverbal communication, but the result of this research showed English teachers used almost all types of the teacher nonverbal communication. In specific description, the researcher found the types of teachers' nonverbal communication.

\section{CONCLUSION}

The purpose of this research is to describe the types of teacher's nonverbal communication SMPN 10 Padang. What are the types of teacher's nonverebal communication at SMPN 10 Padang. Based on theory, there are four type of teacher nonverbal communication. They are kinesics,hapatics,vocalis,proxemics. However, after doing research, the researchers found there are types of teachers are more often used in the learning process. After conducting a research phase in the field to analyze the collected data, the researcher put forward a deep suggestion at this time. First, all teachers can use their type in the process of teaching and learning. Secondly, by knowing the teachers nonverbal communication in teaching, teachers can easy to material and manage the class. And then, students are highly motivated in the learning process because if students are active in the classroom, then the learning process can be effective. In addition, if students are not active in the class. Teachers

can use question and answer with nonverbal communication to motivate students to understand about material.

\section{REFERENCES}

Aggarwal. 2001. Principles Methode and Techniques of Teaching. New Delhi: Vikas Publishing House pvt.Ltd.

Gay, L.R and Peter, Airasian. 2000. Educational Research Competence for Analysis And Application.NY: Prantice-Hall Company. Print 
Hans, Anjali and Hans, Emmanuel. 2015. Kinesics, Haptics and Proxemics: Aspects of Non -Verbal Communication. IOSR Journal Of Humanities And Social Science (IOSR-JHSS). Vol 20, Issue 2, Ver. IV, 47-52. doi: $10.9790 / 0837-20244752$

Joseph, Devito, A. 2002. Human Communication. Boston, MA 02116 www.ablongman.com. Pearson.

Kawulich, Barbara B.2005. Participant Observation as a Data Collection Method. Forum: Qualitative Social Research. Vol.6, No.2.

Panjaitan, T.N, et.al. 2017. Interaction Of Verbal Communication Of The Teacher From The Philippines In The Teaching Activity For Nursery II Students At The Singapore International School, Medan. International Journal of Scientific \& Technology Research. Vol. 6. Issue 07. 33-40.

Sankanarayanan and Sindhu. 2012. Teaching and Learning Nursing. Clyton Panama: Jaypee Brothers Medical Publisher.

Schmitz, Andy. 2012. A Primeran Communication Studies. http://2012. books.lardbuckketorg.

Xu, Jiang. Et.al. 2009. Symbolic Gestures And Spoken Language Are Processed By A Common Neural System. PNAS. 106 (49). 2066420669; https://doi.org/10.1073/pnas.0909197106 